\title{
Labor Studies of the Mid-Atlantic Region
}

\section{Sean Wilentz}

Princeton University

The recent boom in labor history has had a considerable impact in the MidAtlantic region. Recent studies of working class formation and development in Pennsylvania and New York have led to several symposia and discussions: labor history is being taught in colleges and universities from New York to Washington: existing institutes on economic and social history have increasingly turned to topics of direct interest to ILWCH readers. As a first step toward acquainting us all with the area's resources, it seems pertinent to list a few of the more prominent groups and activities.

In New York City, the Columbia University seminar on the history of the working class has offered a stimulating series of papers and forums. Among the features this fall were papers by Herbert Gutman on the state of American labor history and by Susanna Barrows on cafés, drink, and the French working class. Those interested in information about the seminar should contact Helmut Gruber, 425 Riverside Drive, New York, NY 10025. MARHO, the Radical Historians: Organization, continues to sponsor its forums program, with many discussions of interest to labor historians. Contact MARHO, 445 West 59 th Street, New York. NY 10019. The Institute for Research in History, 55 West 44th Street, New York, NY 10036, has helped organize and coordinate numerous projects on labor. Most recently, it has sponsored, with aid from the New York Council for the Humanities, the feature length film, Shop Talk: Modern Times Comes wo a New York Printing Plant, a documentary on class consciousness, automation, and unionization in the late $1970^{\circ} \mathrm{s}$. For information and brochures, write the Institute.

Readers in central New Jersey interested in joining a reading group on labor and Marxist political economy should get in touch with Barry Seldes, Department of Political Science, Rider College. Trenton, NJ 08648. Another reading group, now studying history and political economy, draws members from Philadelphia and the Delaware Valley; those interested should write to Walter Licht. Department of History, University of Pennsylvania, Philadelphia, PA 19104.

The Pennsylvania Labor History Society continues to thrive: the group's recent convention honored the 75 th anniversary of the founding of the IWW and the 
50th anniversary of the death of Mother Jones. Contact Ted Kirsch, American Federation of Teachers. 1816 Chestnut Street, Philadelphia, PA 19103.

Further south, the Regional Economic History Research Center in Wilmington holds both occasional conferences and a regular seminar series. This October, a session on agriculture in Europe and America heard papers from Paul Parvis, Richard Bushman, and Joyce Appleby. Lists of upcoming events, as well as information about the Center's fine series of published working papers, can be obtained from William Mulligan, REHRC, Eleutherian Mills-Hagley Foundation, P.O. Box 3630, Greenville, Wilmington, DE 19807.

This is merely a gleaning of activities already underway. In the future. I hope to add more to the list. along with reports back from conferences and information on archives. It would be a tremendous advance if ILWCH members and readers who live in the area and who plan to be at the AHA in December could meet at some point during the convention to set up a more regular clearing house of information. In the meantime, I would appreciate any news and notes of interest sent to me, c/o Department of History. Princeton University, Princeton, NJ 08544 . 